\title{
Comparative Study of Natural and Synthetic Superdisintegrants in Orodispersible Metformin Tablet
}

\author{
Sachan Anupam Kumar *, Singh Saurabh, Kumar V, Kumari K \\ Dayanand Dinanath College, Institute of Pharmacy, Hamirpur Road, Kanpur, Uttar Pradesh, India
}

\begin{abstract}
A B S T R A C T
Objective: The main objective of this study is comparative study of natural and synthetic superdisintegrants in orodispersible Metformin tablet by using direct compression method and wet granulation method.

Method: Orodispersible Metformin tablet were prepared by wet granulation method and direct compression method by using different synthetic and natural superdisintegrants. Orodispersible tablets (ODTs) have received more interest in the pharmaceutical industry for their easy to use and self medication. ODTs overcome the problem of dysphagia (difficulty in swallowing) in the all group age of patients and advantage particularly for the paediatric and geriatric patients. Metformin hydrochloride $(\mathrm{Hcl})$ is an orally administered antihyperglycemic agent, used in the management of non-insulin dependent (type-2) diabetes mellitus. Metformin orodispersible tablet is prepared by using two methods i.e. direct compression method and wet granulation method. Both methods are applied to prepare Orodispersible Metformin tablet. Orodispersible tablet of Metformin was prepared by using superdisintegrants from both natural and synthetic origin. In natural superdisintegrants we used the mucilage of Fenugreek and Lepidium sativum. In synthetic superdisintegrants we used crospovidone and sodium starch glycolate.

Conclusion: In direct compression and wet granulation method final blend and granules were evaluated the flow properties like bulk density, tapped density, compressibility index, hausner's ratio and angle of repose. The values of precompression parameter evaluated were found to be within the prescribed limit and indicated good flow properties. The data obtained from the post compression methods was studied. Other parameters such as wetting time, water absorption ratio were also evaluated. The formulation (F5) containing 10\% crospovidone prepared by wet granulation method was found the optimize formulation.
\end{abstract}

Keywords: Metformin Hcl, Orodispersible tablets, Superdisintegrants, Direct compression, and Wet granulation.

A R T I C L E I N F 0: Received 12 April 2019; Review Completed 20 May 2019; Accepted 29 May 2019; Available online 15 June 2019

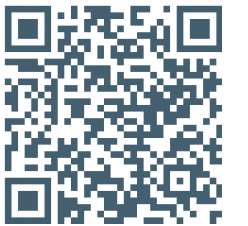

Cite this article as:

Sachan A K, Singh S, Kumar V, Kumari K, Comparative Study of Natural and Synthetic Superdisintegrants In Orodispersible Metformin Tablet, Asian Journal of Pharmaceutical Research and Development. 2019; 7(3):46-53

DOI: http://dx.doi.org/10.22270/ajprd.v7i3.509

*Address for Correspondence:

Anupam Kumar Sachan, Associate Professor, Dayanand Dinanath College, Institute of Pharmacy, Hamirpur Road, Kanpur, Uttar Pradesh, India

\section{INTRODUCTION}

$\mathrm{O}$ rally disintegrating tablets (ODTs) are solid single unit dosage forms that are designed to be placed in the mouth, allowed to disperse or dissolve in the saliva, and then swallowed without the aid of additional water. Orally disintegrating tablets must disperse or dissolve in the mouth quickly, within seconds ${ }^{1}$. During the past decade, the orodispersible technology, which makes tablets dissolve or disintegrate or disperse in the mouth without water intake, has drawn a great deal of attention. The time of disintegration of fast disintegrating tablets is mainly considered to be less than one minute. The fast dissolving solid dosage form turns into a soft paste or liquid form which makes swallowing easier, and thus it is free of risk of choking. In recent years, a variety of improved techniques for delivering drugs have been developed with the aim of enhancing bioavailability, convenience of patient and patient compliance ${ }^{2}$.

Orodispersible tablet of Metformin was preparing by using superdisintegrants from both natural and synthetic origin. In natural superdisintegrants we used the mucilage of Fenugreek and Lepidium sativum. In synthetic superdisintegrants we used crospovidone and sodium starch glycolate. The disintegration time for ODTs generally ranges from several seconds to about a minute. Orodispersible tablets are also known as fast dissolving tablet, mouth dissolving tablets, rapimelt, and porous tablets $^{3}$. 
The European Pharmacopoeia describes fastdisintegrating tablets or 'orodispersible' tablets as 'uncoated tablets intended to be placed in the mouth where they disperse rapidly before being swallowed', and as tablets which should disintegrate within $3 \mathrm{~min}^{4}$.

\section{MATERIALS AND METHODS}

Metformin hydrochloride and microcrystalline cellulose were gift sample by Logos pharma. Crospovidone and sodium starch glycolate a gift sample of Torrent pharmaceuticals. Fenugreek mucilage and Lepidium sativum mucilage extracted from its seed purchase from local market of Kanpur. Magnesium stearate, lactose, talc, PVP K-30, potassium dihydrogen phosphate, sodium hydroxide, chloroform, acetone and ethanol were provided by Institution.

\section{Isolation of Lepidium sativum mucilage}

The Lepidium sativum seeds were purchased from local market of Kanpur. About $100 \mathrm{~g}$ of seeds were soaked in $1000 \mathrm{ml}$ distilled water and $5 \mathrm{ml}$ of chloroform for $24 \mathrm{~h}^{5}$. Then the swell seeds are taken in $1000 \mathrm{ml}$ beaker and set an assembly of lab stirrer and metal blades are moving rapidly and isolate the white mucilaginous mass. Add equal volume of acetone in 1:1. White supernatant coagulatedmass isolated after precipitation by acetone was separated through muslin fabric. Precipitated mucilage was then spread on glass slab and dried at room temperature and then dried at temperature not more then 40 to $45^{\circ} \mathrm{C}$ till it was completely dried. Mucilage obtained was converted into powder by size reduction process and obtained powder was sieved using 60 number sieves and stored in an airtight container.

\section{Isolation of Fenugreek mucilage}

Fenugreek seeds were purchased local market of Kanpur. Seeds were absorbed in water for $48 \mathrm{~h}$ and afterward boiled for $1 \mathrm{~h}$ for complete arrival of mucilage into the water. The material was separated by squash in a muslin fabric to evacuate marc. A similar volume of acetone was added to the filtrate to encourage the mucilage. The mucilage was isolated and dried in a oven at a temperature under $60^{\circ} \mathrm{C}$, powdered material go through 60 number sieves, weighed and put away in desiccators until additionally utilize ${ }^{6}$.

\section{Preparation of tablet}

\section{Direct compression:}

All the weighed quantities of ingredients (except talc and magnesium stearate) were passed through60 number sieves and mixed thoroughly in geometrical proportions and co-grounded for 15 min. Finally, talc and magnesium stearate were added and mixed for $5 \mathrm{~min}^{7}$. Final blend was compressed by using rotary tablet compression machine of 10 stations. The compression force was adjusted to give tablet hardness in range of $2-4 \mathrm{~kg} / \mathrm{cm}^{28}$.

Table 1: Formulation table of orally disintegrating Metformin tablet (direct compression method).

\begin{tabular}{|c|c|c|c|c|c|c|c|c|c|c|}
\hline S. No & Ingredients name (mg) & $\ll$ & F1 & F2 & F3 & F4 & F5 & F6 & F7 & F8 \\
\hline & Superdisintegrant $\%$ & 8 & $7.5 \%$ & & & & $10 \%$ & & & \\
\hline 1. & Metformin Hcl & & 250 & 250 & 250 & 250 & 250 & 250 & 250 & 250 \\
\hline 2. & Crospovidone & & $37.5 \subset /$ & -- & ${ }_{-}^{-}$ & - & 50 & -- & -- & -- \\
\hline 3. & S.S.G. & & -- & 37.5 & - & -- & -- & 50 & -- & -- \\
\hline 4. & Lepidium sativum mucilage & & -- & -- & 37.5 & -- & -- & -- & 50 & -- \\
\hline 5. & Fenugreek mucilage & & -- & -- & -- & 37.5 & -- & -- & -- & 50 \\
\hline 6. & Lactose & & 30 & 30 & 30 & 30 & 30 & 30 & 30 & 30 \\
\hline 7. & Mannitol & & 50 & 50 & 50 & 50 & 50 & 50 & 50 & 50 \\
\hline 8. & Magnesium stearate & & 5 & 5 & 5 & 5 & 5 & 5 & 5 & 5 \\
\hline 9. & Talc & & 10 & 10 & 10 & 10 & 10 & 10 & 10 & 10 \\
\hline 10. & M.C.C. 102 & & 117.5 & 117.5 & 117.5 & 117.5 & 117.5 & 117.5 & 117.5 & 117.5 \\
\hline \multicolumn{3}{|c|}{ Total weight } & 500 & 500 & 500 & 500 & 512.5 & 512.5 & 512.5 & 512.5 \\
\hline
\end{tabular}

\section{Wet granulation Method:}

All the weighed quantities of ingredients were passed through a 60 number sieve prior to mixing. Isopropyl alcohol (IPA) solution of PVK K-30(10\% w/v) was used as a binder to prepare granules ${ }^{9}$. The prepared granules were compressed into tablets by rotary tablet compression machine of 10 stations. Prepare 8 batches of formulations (F1-F8) and prepare 50 tablets in each formulation. 
Table 2: Formulation table of orally disintegrating Metformin tablet (wet granulation method).

\begin{tabular}{|c|c|c|c|c|c|c|c|c|c|}
\hline S. No & Ingredients Name (mg) & F1 & $\mathbf{F} 2$ & F3 & F4 & F5 & F6 & F7 & F8 \\
\hline \multicolumn{2}{|r|}{ Superdisintegrant $\%$} & \multicolumn{4}{|c|}{$7.5 \%$} & \multicolumn{4}{|c|}{$10 \%$} \\
\hline 1. & Metformin HCL & 250 & 250 & 250 & 250 & 250 & 250 & 250 & 250 \\
\hline 2. & Crospovidone & 37.5 & & -- & -- & 50 & -- & -- & -- \\
\hline 3. & S.S.G. & -- & 37.5 & -- & -- & -- & 50 & -- & -- \\
\hline 4. & Lepidium sativum Mucilage & -- & -- & 37.5 & -- & -- & -- & 50 & -- \\
\hline 5. & Fenugreek Mucilage & -- & -- & -- & 37.5 & -- & -- & -- & 50 \\
\hline 6. & Lactose & 30 & 30 & 30 & 30 & 30 & 30 & 30 & 30 \\
\hline 7. & Mannitol & 50 & 50 & 50 & 50 & 50 & 50 & 50 & 50 \\
\hline 8. & PVP K-30 & 10 & 10 & 10 & 10 & 10 & 10 & 10 & 10 \\
\hline 9. & Magnesium Stearate & 5 & 5 & 5 & 5 & 5 & 5 & 5 & 5 \\
\hline 10. & Talc & 10 & 10 & 10 & 10 & 10 & 10 & 10 & 10 \\
\hline 11. & M.C.C. 102 & 107.5 & 107.5 & 107.5 & 107.5 & 107.5 & 107.5 & 107.5 & 107.5 \\
\hline \multicolumn{2}{|c|}{ Total Weight } & 500 & 500 & 500 & 500 & 512.5 & 512.5 & 512.5 & 512.5 \\
\hline
\end{tabular}

\section{EVALUATION PARAMETERS}

\section{Drug Identityfication test:}

\section{UV Spectrophotometric Study}

The $\left(\lambda_{\max }\right)$ was determined by preparing the phosphate buffer ( $\mathrm{pH}$ 6.8) solution of $10 \mu \mathrm{g} / \mathrm{ml}$ and further the sample was scanned at the range of 400-200 $\mathrm{nm}$. It was observed that the maximum absorbance was seen at 232 $\mathrm{nm}$, (using Systronics double beam UV-visible

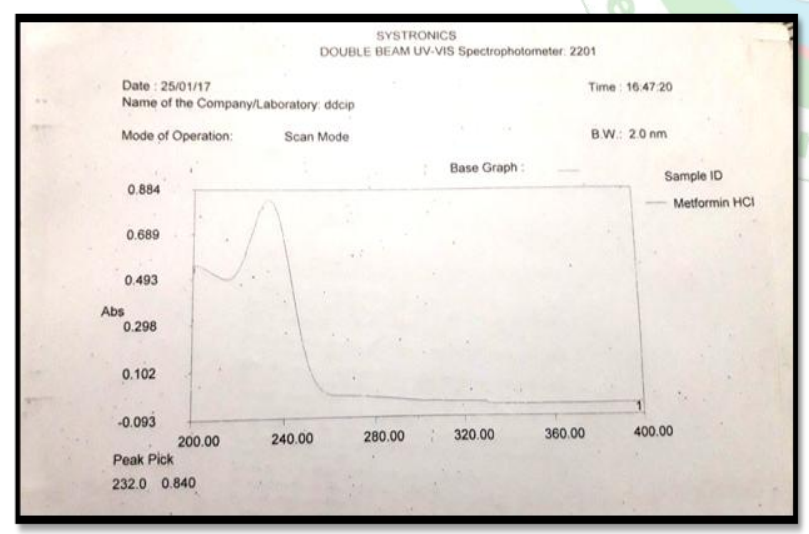

Figure 1: Graph of $\lambda_{\max }$ scan for the drug at $232.0 \mathrm{~nm}$ in phosphate buffer $\mathrm{pH} 6.8$.

Table 3: Interpretation of IR peaks of pure drug Metformin Hcl. ${ }^{12}$.

\begin{tabular}{|l|l|l|l|}
\hline S. No & $\begin{array}{l}\text { Functional } \\
\text { group }\end{array}$ & Range $\left(\mathbf{c m}^{-\mathbf{1}}\right)$ & $\begin{array}{l}\text { Observed } \\
\text { frequency }\left(\mathbf{c m}^{-\mathbf{1}}\right)\end{array}$ \\
\hline $\mathbf{1 .}$ & N-H Stretching & $3500-3100$ & $3372.2-3132.76$ \\
\hline $\mathbf{2 .}$ & C-N Stretching & $1350-1000$ & 1165.4 \\
\hline $\mathbf{3 .}$ & C=N Stretching & $1690-1640$ & 1624.5 \\
\hline
\end{tabular}

spectrophotometer) which was regarded as the $\left(\lambda_{\max }\right)$ of the drug Metformin $\mathrm{Hcl}^{10-11}$.

\section{FTIR spectrophotometric study}

FTIR spectra of pure drug and polymers and physical mixtures were obtained using FTIR spectrophotometer (Perkin Elmer UK) and identify the presence of organic functional groups. The spectrum was recorded in the wavelength region of 4000 to $650 \mathrm{~cm}^{-1}$.

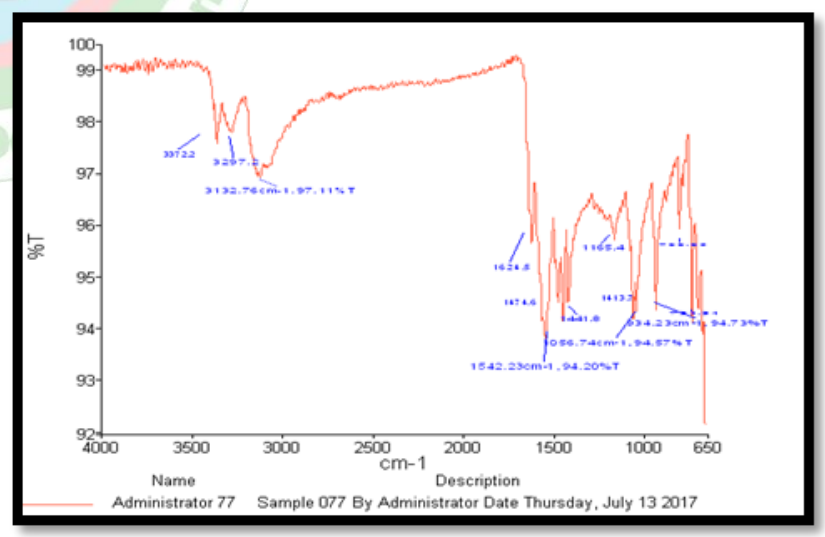

Figure 2: FT-IR spectra of pure drug Metformin $\mathrm{Hcl}$

\section{ANALYTICAL METHODS}

\section{Preparation of pH 6.8 phosphate buffer}

Potassium dihydrogen phosphate, 0.2 M: Dissolve 27.218 $\mathrm{g}$ potassium dihydrogen phosphate in water and dilute with water to $1000 \mathrm{ml}$. Sodium hydroxide, $0.2 \mathrm{M}$ : Dissolve $8 \mathrm{~g}$ of sodium hydroxide in water and dilute with water to $1000 \mathrm{ml}$.

Place $50.0 \mathrm{ml}$ of $0.2 \mathrm{M}$ potassium hydrogen phosphate in a $200 \mathrm{ml}$ volumetric flask, add the $22.4 \mathrm{ml}$ of $0.2 \mathrm{M}$ sodium hydroxide and then add water to volume up to $200 \mathrm{ml}^{13}$. 


\section{Preparation of calibration curve}

Calibration curve of Metformin Hcl was prepared by the stock solution of $100 \mathrm{mg}$ drug in $100 \mathrm{ml}$ of phosphate buffer $\mathrm{pH} 6.8$ in $1 \mathrm{ml}$ of solution contains $1 \mathrm{mg}$ drug. That is $1000 \mu \mathrm{g} / \mathrm{ml}$. Kept for one hour for complete the reaction then filtered with whatmann filter paper. Finally from the stock solution take $1 \mathrm{ml}$ solution and volume make up to $100 \mathrm{ml}$ with the phosphate buffer, $10 \mu \mathrm{g} / \mathrm{ml}$ stock solution II was prepared from which further dilution were prepared of $2 \mu \mathrm{g} / \mathrm{ml}-10 \mu \mathrm{g} / \mathrm{ml}$ and absorbance was taken for each dilution from the UV similarly calibration curve was prepared and absorbance was measured at $232 \mathrm{~nm}$. The graph was then plotted and the correlation coefficient and equation of line was obtained from the data obtained from calibration.

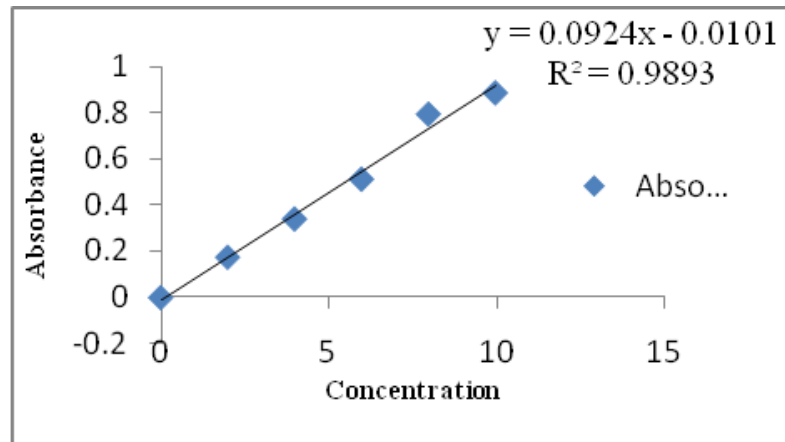

Figure 3: Calibration curve of Metformin $\mathrm{Hcl}$ in phosphate buffer $\mathrm{pH}$ 6.8

\section{PRECOMPRESSION PARAMETERS:-}

Organoleptic property:

Appearance (colour): white

Odour: characteristic

Taste: sweetish

Angle of repose: The diameter of the powder cone was measured and the angle of repose was calculated using the following equation.

$\Theta=\tan ^{-1}(\mathrm{~h} / \mathrm{r})$

Where ' $h$ ' is the height and ' $r$ ' is the radius of the powder cone $^{14}$.

Density: The bulk density (BD) and tapped density (TD) were determined and calculated using the following formulas.

Bulk density=Weight of powder/ Bulk volume

Tapped Density =Weight of powder/Tapped volume

Compressibility: The compressibility index of was determined by Carr's compressibility index.

Carr's Index \% = TD-BD/ TD x 100

Where 'TD' is the tapped density and ' $\mathrm{BD}$ ' is the bulk density.

Hausnser's ratio: Hausner's ratio was determined as the ratio between the tapped density to that bulk density. It is calculated by the formula:

Hausner's Ratio =TD/BD.

Where $\mathrm{TD}=$ tapped density and $\mathrm{BD}=$ bulk density.

\section{Post compression parameters}

Tablet thickness: Thickness and diameter of tablets were important for uniformity of tablet size. Thickness and diameter was measured using vernier calliper ${ }^{15}$.

Weight variation: Twenty tablets were weighed collectively and individually. Average weight was calculated and based on the obtained weights \% weight variation was calculated using the formula,

Average weight- Individual weight

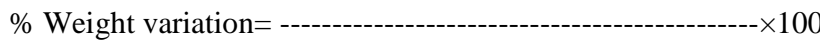

Average weight

\section{Friability:}

The friability of tablets was determined by digital friability test apparatus Roche friabilator in which tablet were subjected to the combined effect of abrasions and shock in a plastic chamber revolving at $25 \mathrm{rpm}$ and dropping the tablets at a height of 6 inches in each revolution. Pre weighed sample of twenty tablets were transferred in the friabilator and allowed to rotate for 100 revolutions (4 min). Later the tablets were dedusted and the tablets were reweighed.

Percentage friability is given by the formula;

Weight of tablet before test - Weight of tablet after test

$\% \mathrm{~F}$ $--\times 100$

Weight of tablet before test

Limits: According to B.P/I.P = Percentage of friability should be not more than $0.8 \%-1.0 \%$

According to U.S.P = Percentage of friability should be not more than $4 \%$.

Hardness (crushing strength): The resistance of tablets to shipping or breakage under conditions of storage, transportation and handling before usage depends on its hardness. The hardness of tablet of each formulation was measured by Monsanto hardness tester. The hardness was measured in $\mathrm{kg} / \mathrm{cm}^{2}{ }^{16}$.

Wetting time and water absorption ratio: To determine the wetting time of ODTs, a piece of tissue paper was taken and it was folded twice and placed in culture dish $(\mathrm{d}=6.5 \mathrm{~cm})$ containing about $6 \mathrm{ml}$ of purified water. An ODT was placed on tissue paper. The time required for complete wetting was measured. To determine the water absorption ratio, the wetted tablets were transferred to a tissue paper and wiped off any excess water and weighed immediately. The water absorption ratio was calculated by following formula given as Eq:

$$
\mathrm{R}=\frac{\mathrm{Wa}-\mathrm{Wb}}{\mathrm{Wa}} \times 100
$$

Where, $\mathrm{Wb}$ is the weight of tablet before study

Wa is the weight of tablet after study ${ }^{17}$

Drug content: Weigh and powder 20 tablets. Weigh accurately a quantity of the powder containing about $0.1 \mathrm{~g}$ of Metformin Hydrochloride, shake with $70 \mathrm{ml}$ of water for $15 \mathrm{~min}$, dilute to $100.0 \mathrm{ml}$ with water and filter. Dilute $10.0 \mathrm{ml}$ of the filtrate to $100.0 \mathrm{ml}$ with water. Further dilute $10.0 \mathrm{ml}$ to $100.0 \mathrm{ml}$ with water and measure the 
absorbance of the resulting solution at the maximum at about 232nm. Calculate the content of Metformin hydrochloride at given specific absorbance ${ }^{18}$.

\section{In-vitro Disintegration test}

Disintegration test is a method to evaluate the rate of disintegration of tablets. It is also defined as break down of solid dosage form into smaller particles when it is disintegrated. Place 1 tablet in each of the 6 tubes and added a disc to each tube. Maintain the temperature of the disintegration media at $37 \pm 2^{\circ} \mathrm{C}$ as specified in the monographs. At the end of time limit specified, left the basket from fluid and observe the tablets. If 1 or 2 tablets fail to disintegrate completely repeat the test on 12 additional tablets. Not less than 16 out of 18 tablets tested disintegrate completely.

\section{In-vitro Dissolution study}

The in-vitro dissolution study of Metformin hydrochloride orodispersible tablet was performed USP dissolution testing apparatus type II with a paddle stirrer. The speed of rotation of paddle was set at $50 \mathrm{rpm}$. Dissolution study was performed using $900 \mathrm{ml}$ of phosphate buffer $\mathrm{pH} 6.8$ maintained at a temperature of $37 \pm 0.5{ }^{\circ} \mathrm{C}$. At different time intervals, $5 \mathrm{ml}$ of the samples were withdrawn and replaced with $5 \mathrm{ml}$ of drug-free dissolution medium or phosphate buffer pH 6.8 at maintained temperature of 37 $\pm 0.5^{\circ} \mathrm{C}$. The samples withdrawn were analyzed, for drug release and release kinetics, spectrophotometerically using UV spectrophotometer (after suitable dilutions). ${ }^{19}$

In-vitro Drug release kinetics: In order to find out the mechanism of drug release, the in-vitro dissolution data were applied to various kinetics models. The best fit with

\section{Evaluation of powder blend and granules}

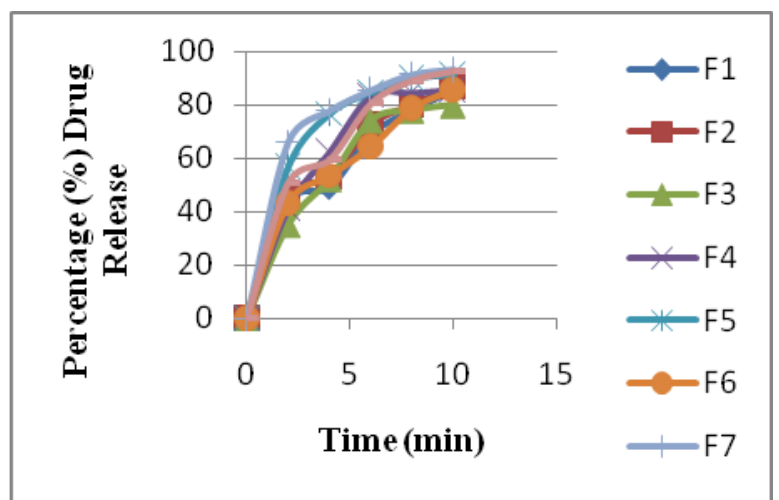

Figure 4: In-vitro release of orodispersible Metformin tablet formulation F1-F8 (direct compression method)

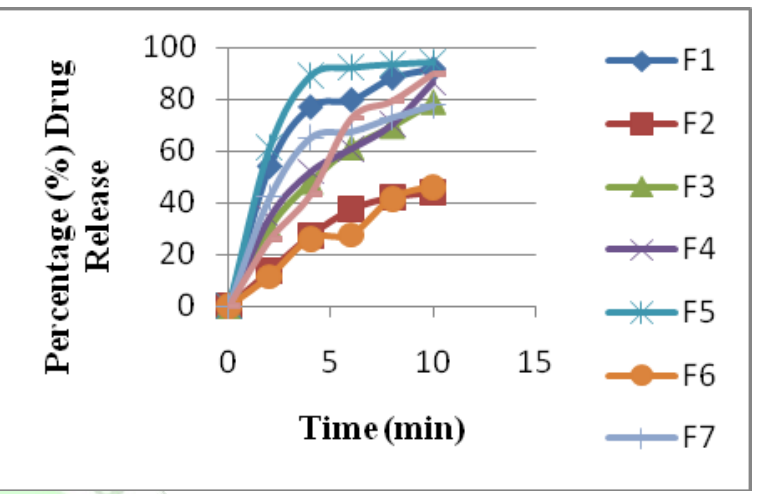

Figure 5: In-vitro release of orodispersible Metformin tablet formulation F1-F8 (wet granulation method)

highest regression coefficient values $\left(\mathrm{R}^{2}\right)$ predicted by Higuchi model then other models. The release patterns follow the Higuchi model.

Table 9: Precompression parameters of Metformin orodispersible powder blend (direct compression method).

\begin{tabular}{|c|c|c|c|c|c|c|}
\hline $\begin{array}{l}\text { Batch } \\
\text { No. }\end{array}$ & $\begin{array}{l}\text { Angle of repose } \\
(\theta) \pm \text { SD }\end{array}$ & $\begin{array}{l}\text { Bulk density } \\
(\mathrm{gm} / \mathrm{ml}) \pm \mathrm{SD}\end{array}$ & $\begin{array}{l}\text { Tapped density } \\
(\mathrm{gm} / \mathrm{ml}) \pm \mathrm{SD}\end{array}$ & $\begin{array}{l}\text { Carr's index } \\
(\%) \pm \text { SD }\end{array}$ & $\begin{array}{l}\text { Hausner's ratio } \\
(\text { HR }) \pm \text { SD }\end{array}$ & Flow \\
\hline F1 & $32.61 \pm 0.40$ & $0.420 \pm 0.001$ & $0.673 \pm 0.010$ & $28.67 \pm 0.12$ & $1.40 \pm 0.002$ & Poor \\
\hline F2 & $37.91 \pm 1.07$ & $0.422 \pm 0.002$ & $0.526 \pm 0.002$ & $19.77 \pm 0.16$ & $1.24 \pm 0.003$ & Fair \\
\hline F3 & $37.01 \pm 1.65$ & $0.536 \pm 0.007$ & $0.749 \pm 0.003$ & $28.43 \pm 0.50$ & $1.39 \pm 0.005$ & Poor \\
\hline F4 & $37.37 \pm 1.16$ & $0.567 \pm 0.003$ & $0.667 \pm 0.007$ & $14.35 \pm 0.69$ & $1.16 \pm 0.003$ & Fair \\
\hline F5 & $37.56 \pm 1.02$ & $0.532 \pm 0.008$ & $0.706 \pm 0.004$ & $24.64 \pm 0.38$ & $1.32 \pm 0.002$ & Poor \\
\hline F6 & $36.83 \pm 0.58$ & $0.628 \pm 0.006$ & $0.750 \pm 0.005$ & $16.26 \pm 0.47$ & $1.19 \pm 0.005$ & Good \\
\hline F7 & $37.34 \pm 0.51$ & $0.570 \pm 0.003$ & $0.726 \pm 0.006$ & $21.48 \pm 0.31$ & $1.27 \pm 0.008$ & Fair \\
\hline F8 & $35.29 \pm 0.44$ & $0.636 \pm 0.005$ & $0.778 \pm 0.008$ & $18.25 \pm 0.32$ & $1.22 \pm 0.002$ & Fair \\
\hline
\end{tabular}

Table10: Precompression parameters of Metformin orodispersible powder blend (wet granulation method)

\begin{tabular}{|c|c|c|c|c|c|c|}
\hline $\begin{array}{l}\text { Batch } \\
\text { No. }\end{array}$ & $\begin{array}{l}\text { Angle of repose } \\
(\theta) \pm \mathrm{SD}\end{array}$ & $\begin{array}{l}\text { Bulk density } \\
(\mathrm{gm} / \mathrm{ml}) \pm \mathrm{SD}\end{array}$ & $\begin{array}{l}\text { Tapped density } \\
(\mathrm{gm} / \mathrm{ml}) \pm \mathrm{SD}\end{array}$ & $\begin{array}{l}\text { Carr's index } \\
(\%) \pm \text { SD }\end{array}$ & $\begin{array}{l}\text { Hausner's ratio } \\
(\text { HR }) \pm \text { SD }\end{array}$ & Flow \\
\hline F1 & $28.22 \pm 0.88$ & $0.592 \pm 0.002$ & $0.691 \pm 0.006$ & $14.32 \pm 0.22$ & $1.16 \pm 0.004$ & Excellent \\
\hline F3 & $27.18 \pm 0.80$ & $0.597 \pm 0.003$ & $0.708 \pm 0.005$ & $15.67 \pm 0.44$ & $1.18 \pm 0.008$ & Good \\
\hline F4 & $28.37 \pm 1.12$ & $0.568 \pm 0.007$ & $0.705 \pm 0.003$ & $19.43 \pm 0.56$ & $1.24 \pm 0.007$ & Fair \\
\hline F6 & $27.62 \pm 0.96$ & $0.581 \pm 0.002$ & $0.669 \pm 0.010$ & $13.15 \pm 0.33$ & $1.15 \pm 0.006$ & Good \\
\hline F7 & $27.93 \pm 1.02$ & $0.567 \pm 0.004$ & $0.732 \pm 0.004$ & $23.54 \pm 0.47$ & $1.29 \pm 0.003$ & Poor \\
\hline F8 & $29.77 \pm 1.06$ & $0.567 \pm 0.003$ & $0.731 \pm 0.008$ & $21.20 \pm 0.58$ & $1.26 \pm 0.008$ & Fair \\
\hline
\end{tabular}




\section{Evaluation of prepared orodispersible Metformin Hcl tablet}

Table 11: Post compression properties of orodispersible Metformin tablet (direct compression method)

\begin{tabular}{|c|c|c|c|c|c|}
\hline $\begin{array}{c}\text { Batch } \\
\text { No. }\end{array}$ & $\begin{array}{c}\text { Diameter } \\
(\mathbf{m m})\end{array}$ & $\begin{array}{c}\text { Hardness } \\
\left(\mathbf{k g} / \mathbf{c m}^{2}\right) \pm \text { S.D }\end{array}$ & $\begin{array}{c}\text { Thickness } \\
(\mathbf{m m}) \pm \text { S.D }\end{array}$ & $\begin{array}{c}\text { Friability (\%) } \\
\pm \text { S.D }\end{array}$ & $\begin{array}{c}\text { Drug Content } \\
(\mathbf{\%})\end{array}$ \\
\hline F1 & 10.5 & $2.2 \pm 0.60$ & $6.4 \pm 0.033$ & $10.25 \pm 0.08$ & 96.7 \\
\hline F2 & 10.5 & $2.35 \pm 0.50$ & $5.96 \pm 0.029$ & $1.97 \pm 0.02$ & 93.1 \\
\hline F3 & 10.5 & $2.80 \pm 0.47$ & $6.6 \pm 0.025$ & $0.94 \pm 0.04$ & 95.6 \\
\hline F4 & 10.5 & $2.75 \pm 0.35$ & $5.76 \pm 0.032$ & $1.13 \pm 0.05$ & 90.8 \\
\hline F5 & 10.5 & $2.90 \pm 0.36$ & $6.6 \pm 0.025$ & $0.89 \pm 0.02$ & 95.6 \\
\hline F6 & 10.5 & $2.95 \pm 0.30$ & $5.93 \pm 0.035$ & $0.88 \pm 0.05$ & 91.6 \\
\hline F7 & $\mathbf{1 0 . 5}$ & $\mathbf{3 . 2 0} \pm \mathbf{0 . 4 4}$ & $\mathbf{6 . 5} \pm \mathbf{0 . 0 3 2}$ & $\mathbf{0 . 8 6} \pm \mathbf{0 . 0 3}$ & $\mathbf{9 2 . 4}$ \\
\hline F8 & 10.5 & $3.00 \pm 0.40$ & $5.8 \pm 0.023$ & $0.49 \pm 0.04$ & 90.5 \\
\hline
\end{tabular}

Table12: Post compression properties of Orodispersible Metformin tablet (wet granulation method)

\begin{tabular}{|l|l|l|l|l|l|}
\hline $\begin{array}{l}\text { Batch } \\
\text { No. }\end{array}$ & $\begin{array}{l}\text { Diameter } \\
(\mathbf{m m})\end{array}$ & $\begin{array}{l}\text { Hardness } \\
\left(\mathbf{k g} / \mathbf{c m}^{2}\right) \pm \text { S.D }\end{array}$ & $\begin{array}{l}\text { Thickness } \\
(\mathbf{m m}) \pm \text { S.D }\end{array}$ & $\begin{array}{l}\text { Friability } \\
\pm \text { S.D }\end{array}$ & $\begin{array}{l}\text { Drug content } \\
(\mathbf{\%})\end{array}$ \\
\hline F1 & 10.5 & $3.00 \pm 0.40$ & $5.73 \pm 0.019$ & $0.75 \pm 0.07$ & 93.5 \\
\hline F2 & 10.5 & $3.20 \pm 0.62$ & $6.13 \pm 0.026$ & $0.74 \pm 0.09$ & 91.2 \\
\hline F3 & 10.5 & $3.40 \pm 0.46$ & $6.06 \pm 0.019$ & $0.39 \pm 0.04$ & 94.6 \\
\hline F4 & 10.5 & $3.30 \pm 0.62$ & $6.1 \pm 0.016$ & $0.84 \pm 0.10$ & 94.8 \\
\hline F5 & $\mathbf{1 0 . 5}$ & $\mathbf{3 . 2 0 \pm 0 . 3 5}$ & $\mathbf{5 . 7 6 \pm 0 . 0 2 6}$ & $\mathbf{0 . 5 9 \pm 0 . 0 5}$ & $\mathbf{9 6 . 6}$ \\
\hline F6 & 10.5 & $3.40 \pm 0.44$ & $6.16 \pm 0.021$ & $0.74 \pm 0.02$ & 89.8 \\
\hline F7 & 10.5 & $5.00 \pm 0.80$ & $6.09 \pm 0.014$ & $0.59 \pm 0.06$ & 93.5 \\
\hline F8 & 10.5 & $4.60 \pm 0.55$ & $6.13 \pm 0.038$ & $0.54 \pm 0.03$ & 90.5 \\
\hline
\end{tabular}

Table13: Post compression properties of orodispersible Metformin tablet (direct compression method).

\begin{tabular}{|l|l|l|l|l|}
\hline $\begin{array}{l}\text { Batch } \\
\text { No. }\end{array}$ & $\begin{array}{l}\text { Weight variation } \\
(\mathbf{m g}) \pm \text { S.D }\end{array}$ & $\begin{array}{l}\text { Wetting time } \\
(\mathbf{s e c}) \pm \text { S.D }\end{array}$ & $\begin{array}{l}\text { Disintegration time } \\
(\mathbf{s e c}) \pm \text { S.D }\end{array}$ & $\begin{array}{l}\text { Water absorption } \\
\text { ratio }(\%)\end{array}$ \\
\hline F1 & $496.6 \pm 0.37$ & $22 \pm 1.16$ & $44 \pm 1.03$ & 43.32 \\
\hline F2 & $502.8 \pm 0.95$ & $34 \pm 1.40$ & $56 \pm 1.04$ & 49.78 \\
\hline F3 & $503.7 \pm 0.85$ & $30 \pm 1.18$ & $90 \pm 1.16$ & 56.74 \\
\hline F4 & $498.3 \pm 0.44$ & $46 \pm 1.20$ & $150 \pm 1.62$ & 53.82 \\
\hline F5 & $517.8 \pm 0.98$ & $20 \pm 1.03$ & $85 \pm 1.04$ & 51.26 \\
\hline F6 & $508.4 \pm 0.75$ & $36 \pm 0.75$ & $55 \pm 1.40$ & 50.68 \\
\hline F7 & $\mathbf{5 1 6 . 6 \pm 0 . 6 5}$ & $\mathbf{2 6} \pm \mathbf{0 . 7 0}$ & $\mathbf{4 2 \pm 0 . 7 5}$ & $\mathbf{5 8 . 7 8}$ \\
\hline F8 & $509.9 \pm 0.78$ & $45 \pm 1.28$ & $145 \pm 1.56$ & 55.65 \\
\hline
\end{tabular}

Table14: Post compression properties of Orodispersible Metformin tablet (wet granulation method)

\begin{tabular}{|l|l|l|l|l|}
\hline $\begin{array}{l}\text { Batch } \\
\text { No. }\end{array}$ & $\begin{array}{l}\text { Weight variation } \\
(\mathbf{m g}) \pm \text { S.D }\end{array}$ & $\begin{array}{l}\text { Wetting time } \\
(\mathbf{s e c}) \pm \text { S.D }\end{array}$ & $\begin{array}{l}\text { Disintegration time } \\
(\mathbf{s e c}) \pm \text { S.D }\end{array}$ & $\begin{array}{l}\text { Water absorption } \\
\text { ratio (\%) }\end{array}$ \\
\hline F1 & $504.8 \pm 1.25$ & $27 \pm 1.20$ & $26 \pm 1.16$ & 59.27 \\
\hline F2 & $492.6 \pm 0.93$ & $40 \pm 1.35$ & $65 \pm 1.50$ & 45.68 \\
\hline F3 & $506.5 \pm 0.78$ & $36 \pm 0.90$ & $52 \pm 0.85$ & 53.40 \\
\hline F4 & $502.9 \pm 0.45$ & $55 \pm 1.50$ & $160 \pm 2.15$ & 44.56 \\
\hline F5 & $\mathbf{5 1 2 . 8 \pm 0 . 8 5}$ & $\mathbf{2 6} \pm \mathbf{1 . 1 5}$ & $\mathbf{2 0 \pm 0 . 7 5}$ & $\mathbf{6 2 . 5 9}$ \\
\hline F6 & $518.5 \pm 0.95$ & $38 \pm 1.12$ & $68 \pm 1.70$ & 48.15 \\
\hline F7 & $510.2 \pm 0.68$ & $33 \pm 0.85$ & $49 \pm 1.04$ & 56.25 \\
\hline F8 & $518.3 \pm 0.35$ & $52 \pm 1.16$ & $158 \pm 1.04$ & 47.33 \\
\hline
\end{tabular}




\section{STABILITY STUDIES (accelerated stability study)}

Stability studies were done according to ICH guideline to assess the drug and formulation stability. Stability studies are done to predict the shelf life of the formulation by accelerating the rate of decomposition by increasing the storage temperature and appropriate relative humidity. This is called as accelerated stability study. In general case the formulations were subjected to stability study at $40 \pm 2{ }^{\circ} \mathrm{C}$ and $75 \pm 5 \% \mathrm{RH}$ for 6 months. At the accelerated storage condition, a minimum of three sampling time points e.g. 1, 3 and 6 months, from a 6 month study is recommended ${ }^{20}$. The samples were evaluated for physical change, hardness, friability, drug content and percentage drug release during the stability studies ${ }^{21}$.

Table15: Stability study of optimized formulation of Metformin ODTs (direct compression method) F7.

\begin{tabular}{|l|l|l|l|l|l|}
\hline $\begin{array}{l}\text { Time (Months) / At } \\
\mathbf{4 0} \pm \mathbf{2}^{\mathbf{0}} \mathbf{C}, \mathbf{7 5} \pm \mathbf{5} \% \mathbf{R H}\end{array}$ & Appearance & $\begin{array}{l}\text { Hardness } \\
\left(\mathbf{k g} / \mathbf{c m}^{\mathbf{2}}\right) \pm \text { S.D }\end{array}$ & $\begin{array}{l}\text { Drug content } \\
(\mathbf{\%})\end{array}$ & $\begin{array}{l}\text { Friability } \\
(\mathbf{\%}) \pm \text { S.D }\end{array}$ & $\begin{array}{l}\text { Disintegration } \\
\text { time(sec) } \pm \text { S.D }\end{array}$ \\
\hline $\mathbf{1}$ Month & No Change & $3.20 \pm 0.44$ & 92.4 & $0.86 \pm 0.05$ & $41 \pm 065$ \\
\hline $\mathbf{3}$ Month & No Change & $3.10 \pm 0.44$ & 92.0 & $0.84 \pm 0.03$ & $42 \pm 0.75$ \\
\hline $\mathbf{6}$ Month & No Change & $3.00 \pm 0.44$ & 91.0 & $0.85 \pm 0.04$ & $42 \pm 0.75$ \\
\hline
\end{tabular}

Table16: Stability study of optimized formulation of Metformin ODTs (wet granulation method) F5

\begin{tabular}{|l|l|l|l|l|l|}
\hline $\begin{array}{l}\text { Time (Months) / At } \\
\mathbf{4 0} \pm \mathbf{2}^{\mathbf{0}} \mathbf{C} \mathbf{7 5} \pm \mathbf{5 \%} \mathbf{~ R H}\end{array}$ & Appearance & $\begin{array}{l}\text { Hardness } \\
\left(\mathbf{k g} / \mathbf{c m}^{\mathbf{2}} \mathbf{\pm} \mathbf{S . D}\right.\end{array}$ & $\begin{array}{l}\text { Drug content } \\
\mathbf{( \% )}\end{array}$ & $\begin{array}{l}\text { Friability } \\
(\boldsymbol{\%}) \pm \text { S.D }\end{array}$ & $\begin{array}{l}\text { Disintegration } \\
\text { time }(\mathbf{s e c}) \pm \text { S.D }\end{array}$ \\
\hline $\mathbf{1}$ Month & No Change & $3.20 \pm 0.35$ & 96.6 & $0.57 \pm 0.07$ & $20 \pm 0.75$ \\
\hline $\mathbf{3}$ Month & No Change & $3.15 \pm 0.35$ & 96.6 & $0.59 \pm 0.05$ & $20 \pm 0.75$ \\
\hline 6 Month & No Change & $3.15 \pm 0.35$ & 96.0 & $0.58 \pm 0.04$ & $21 \pm 0.85$ \\
\hline
\end{tabular}

\section{RESULT AND DISCUSSION}

The Metformin orodispersible formulation were prepared by direct compression method (F1-F8) and wet granulation method (F1-F8), in each method eight formulation batch is designed, using higher and lower level of superdisintegrants and employing natural and synthetic superdisintegrants. Sodium starch glycolate, crospovidone, Lepidium sativum mucilage and Fenugreek mucilage were used as superdisintegrants. For each designed formulation, blend of drug and excipients were prepared and evaluate for precompression parameters. The $\lambda_{\max }$ of Metformin drug was found to be $232 \mathrm{~nm}$ in phosphate buffer $\mathrm{pH} 6.8$. The values of precompression parameters evaluated were found to be within the prescribed limits and indicated good flow properties. The percentage drug content of all the tablets were found in the range of $89.8 \%$ to $96.6 \%$, which was in the acceptable limit. In each method there was one optimizing formulation in direct compression method F7 and one optimize formulation in wet granulation method F5.

The optimize formulation of direct compression method F7 hardness of the tablet was found to be $3.20 \mathrm{~kg} / \mathrm{cm}^{2}$ and friability value were less than $1 \%$. The percentage of drug released for formulation $\mathrm{F} 7$ showed better drug release of $93.49 \%$, containing $10 \%$ of Lepidium sativum mucilage (natural superdisintegrant), among all the eight

\section{REFERENCE}

1. Hahm HA, AugsburgerLL. Orally disintegrating tablets and related tablet formulations. 3rd ed. New York: Informa Healthcare; 2008. P.40-8.

2. Kumar R, Garg S, Chandra A, Sharma VK. Orodispersible Tablets: A splendid Form of Oral Delivery System-An Update Review. IJPBA. 2016; 7(4):1-12.

3. Pagar R, Ahir SR, Yallatikar T, Wagh M. Review on Orodispersible Tablets. IJPRS.2015; 1(4):302-3.

4. Chandrasekhar R, Hassan Z, Alhusban F, Smith MA, Mohammad RA. The role of Formulation Excipients in the Development of formulations, confirming it to be the optimize formulation in direct compression method .The optimize formulation of wet granulation method F5 hardness of the tablet was found to be $3.20 \mathrm{~kg} / \mathrm{cm}^{2}$ and friability value were less than $1 \%$. The percentage of drug released for formulation F5 showed better drug release of $94.45 \%$, containing $10 \%$ of crospovidone(synthetic superdisintegrant), among all the eight formulations, confirming it to be the optimize formulation in wet granulation method.

The both optimize formulation of each method compared by stability study (accelerated stability study). The F5 formulation of wet granulation method showed better result.

\section{CONCLUSION}

In direct compression and wet granulation final blend and granules were evaluated the flow properties like bulk density, tapped density, compressibility index, hausner's ratio and angle of repose. The values of precompression parameter evaluated were found to be within the prescribed limit and indicated good flow properties. The data obtained from the post compression methods was studied. Other parameters such as wetting time, water absorption ratio were also evaluated. The formulation (F5) containing $10 \%$ crospovidone prepared by wet granulation method was found the optimize formulation.

Lyophilised Fast-disintegrating Tablets. European Journal of Pharmaceutics and Biopharmaceutics.2009; 72:119-29.

5. Kilor V, Bramhe NN. Development of Effective Extraction Method for Lepidium SativumSeed Mucilage with Higher Yield. JAPER. 2014; 4(3):354-60.

6. Shirsand SB, Suresh S, Para MS, Swamy PV, Kumar DN. Plantago Ovate Mucilage in the Design of Fast Disintegrating Tablets. IJPS. 2009; 71(1):41-6.

7. Gandhi PP, Vaidya KA, Shelak GT, Yadav JD, Kulkarni PR Formulation and Evaluation of Metformin Hydrochloride Fast 
Disintegrating Tablets by using Polacriline Potassium NF from Different Source as Superdisintegrants. IJPPS.2010; 2(2):55-7.

8. Elkhodiary KA, Hassan MA, Afifi SA. Formulation and Optimization of Orodispersible Tablets of Flutamide. Saudi Pharmaceutical Journal.2014; 22:53-61.

9. Mohapatra A, Parikh RK, Gohrl MC. Formulation Development and Evaluation of Patient Friendly Dosage Form of Metformin, part-1: Orally Disintegrating Tablets.AJP, 2008; 167-71.

10. Rani PA, Archana N, Teja SP, Vikas MP, Kumar SM, Sekaran BC. Formulation and Evaluation of Orodispersible Metformin Tablets: A Comparative Study on Isphagula Husk and Crospovidone as Superdisintegrants. IJAP. 2010; 2(3):15-21.

11. Sachan AK, Gupta A. Formulation and Evaluation of Bilayer Tablets of Nitazoxanide. Der pharmacialettre. 2017; 9(7):1-9.

12. Pavia DL, Lampman GM, Kriz GS. Introduction to spectroscopy. 3rd ed. United states of America: Thomas Learning; 2001. p. 25-33.

13. Indian Pharmacopeia. $3^{\text {rd }}$ ed. Government of India, Controller ofPublications: New Delhi; 2007. p. 740-42.

14. Jaya S, Amala V. Formulation and In-vitroEvaluation of Oral Disintegrating Tablets of Amlodipine Besylate. IJAP. 2019; 11(1): 49-54.
15. Ansel HC, Popovich NG, Allen LV. Pharmaceutical dosage forms anddrug delivery systems. 4th ed. Wolter Kluwer:LippioncottWillians and Wilkins; 1995 . p. 340-89.

16. Aulton ME. Aulton's pharmaceutics. The design and manufacture of medicines.3rd ed. Churchill Livingstone: Elsiever Publication; 2007. p. 254-96.

17. Dave V, Yadav RB, Ahuja R, Yadav S. Formulation Design and Optimization of Novel Fast Dissolving Tablet of Chlorphemiramine Maleate by using Lyophilzation Techniques. Bulletin of Faculty of Pharmacy, Cairo University.2017; 55:31-9.

18. Indian Pharmacopeia. $3^{\text {rd }}$ ed. Government of India, Controller of Publications; New Delhi: 2007. p. 354-5

19. Senthil A, Sivakumar T, Narayanaswamy VB, Ashish SP, Viral GP. Formulation and Evaluation of Metoprolol Tartarate by Direct Compression using Super Disintegrants.IJRAP. 2011; 2(1):224-9.

20. ICH Harmonised Tripartite Guideline. Stability testing of new drug substances and products Q1A (R2); Current Step 4 version: 2003. p. 3-6.

21. Sachan AK, Tripathi K, Vishnoi G, Rasheed A, Sharma R, Gangwar SS. Formulation Development and Characterization of Piroxicam Fast Dissolving Tablets Approved for the Treatment of Arthritis. IJDR. 2015; 5(2): 3440-46. 